\title{
ANALYSIS OF THE STOCK MARKET AND PERSPECTIVE DIRECTIONS FOR ITS DEVELOPMENT
}

\author{
Taina Zavora*, PhD (Economics), associate Professor \\ Poltava National Technical Yuri Kondratyuk University \\ Yevhenii Kuzmenko \\ Politechnika Białostocka, Bialystok, Poland
}

ORCID*0000-0003-3289-7177

(C) Zavora T., 2019.

(C) Kuzmenko Y., 2019.

Стаття отримана редакиією 22.07.2019 p.

The article was received by editorial board on 22.07.2019

Introduction. An actively functioning stock market which effectively regulated by government agencies and self-regulatory organizations is an integral part of a successful financial market of the country and the entire economy as a whole. The stock market exists in Ukraine for 26 years and has not become a leading means of attracting investments to various sectors of the economy by foreign and domestic investors and continues. Unfortunately, stock market in Ukraine continues to exist separately from the real sector of the economy.

The Ukrainian stock market suffers from a lack of high-quality financial instruments and low liquidity under available instruments.

The share stock market segment is only $43.91 \%$, which indicates a lack of development of this segment.

The development of the stock market segment accounts for only $43.91 \%$ and remains inadequate. Another problem is the lack of awareness of the public about the opportunities offered by the stock market and, consequently, its low level of involvement in trading and investing in the stock market. Accordingly, the actual task is to analyze the stock market of Ukraine and determine the perspective directions of its development.

The main chapter. Problems and prospects of development of the domestic stock market are devoted to numerous studies and publications by such authors as: V. Hrynova, Yu. Kravchenko, L. Nazarenko, V. Oskolskyi, V. Sheludko and others. The authors summarize that the stock market is the one of the most important segments of the national market economy system, which transforms investment savings and redistributes financial flows between economic entities $[6,7]$.

The purpose of this article is to analyze the peculiarities of the functioning of the stock market in Ukraine and to identify the main problems of its development, as well as the directions of their solutions.

The Ukrainian stock market is a complex multicomponent structure. Its full analysis should include the following main components: analysis of trading volumes on the stock market for different periods, analysis of capitalization and stock indexes, analysis of the structure of the stock market by the organizers of trading, as well as analysis of the structure of the stock market in terms of instruments.

The analysis of the stock market by the determined indicators allowed to reveal such tendencies of its functioning (Fig. 1) [5].

Analysis of major Ukrainian stock indexes UX and PFTS has shown a positive dynamic of Ukrainian stock prices in 2016 and 2017.

UX has increased by $71.27 \%$ in 2017 , one of the highest growth rates in the world. PFTS also demonstrated positive dynamic and grew up by $18.82 \%$ in 2017 .

Nevertheless, on modern stage of Ukrainian stock market development, simple analysis of indexes does not allow to obtain a correct picture of stock market condition, which determines the necessity of tradevolume analysis (Fig. 2) 


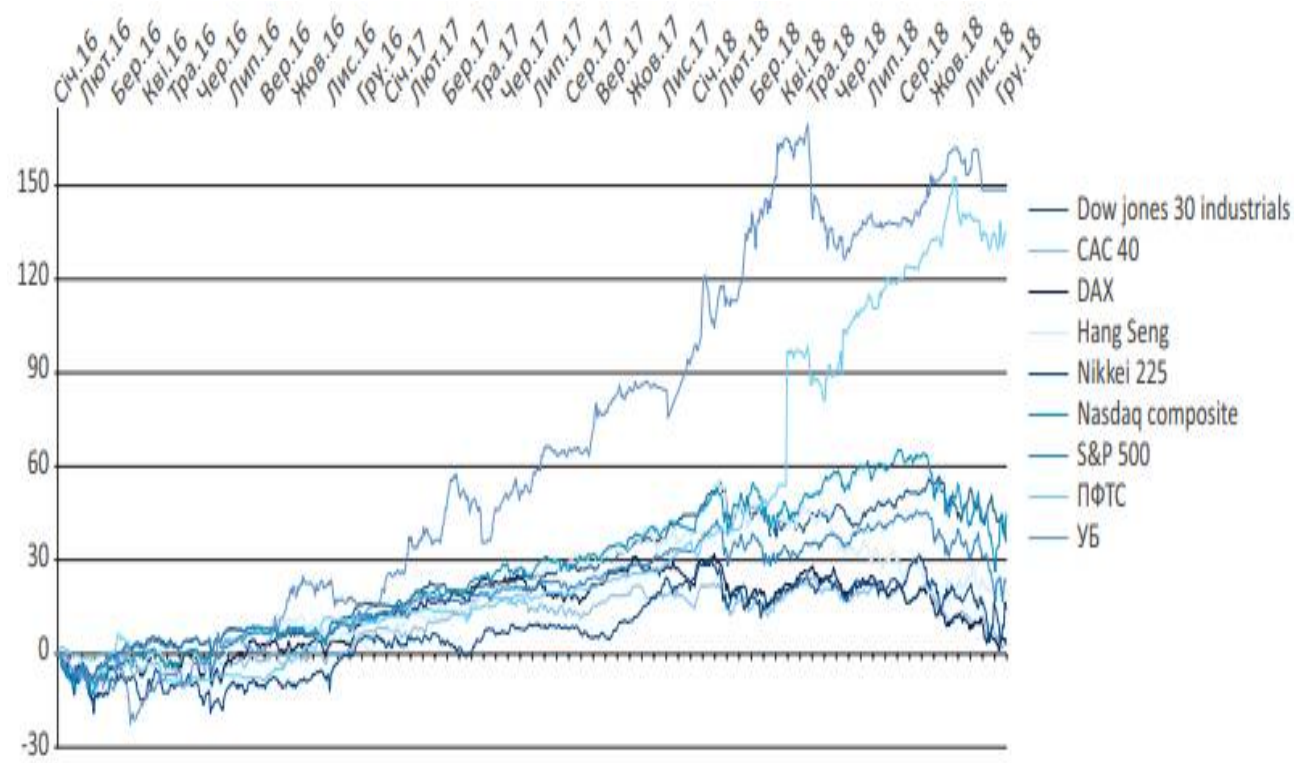

Fig. 1. Ukrainian and world indexes in 2016-2018

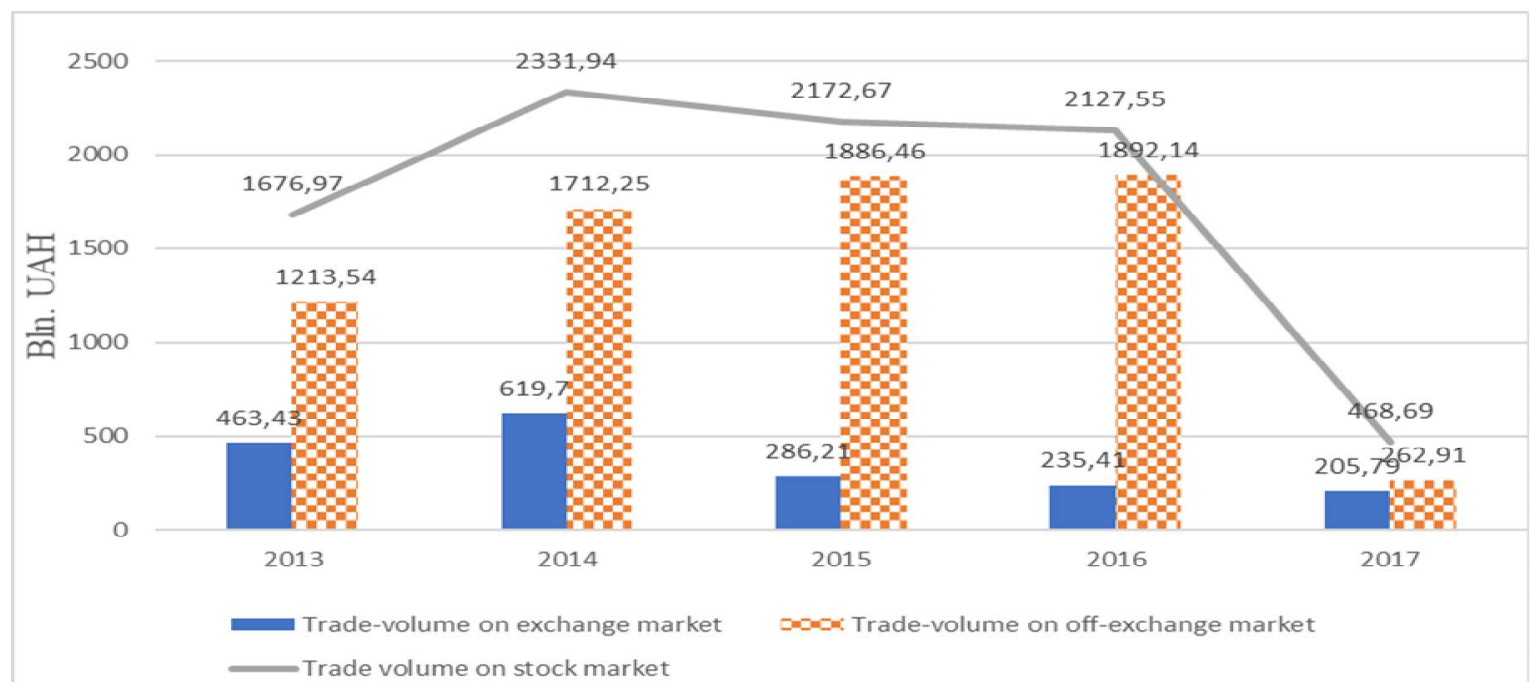

Fig. 2. Trade-volumes on stock market in 2013-2017, BLN. UAH

2017 was marked by significant drop in trade-volumes on Ukrainian stock-market. Overall, trading has dropped from 2127,55 Bln. UAH in 2016 to 468,69 Bln. UAH in 2017 (-77,97\%). This drop indicates extremely low activity on Ukrainian stock-market and loose of investors' interest [5].

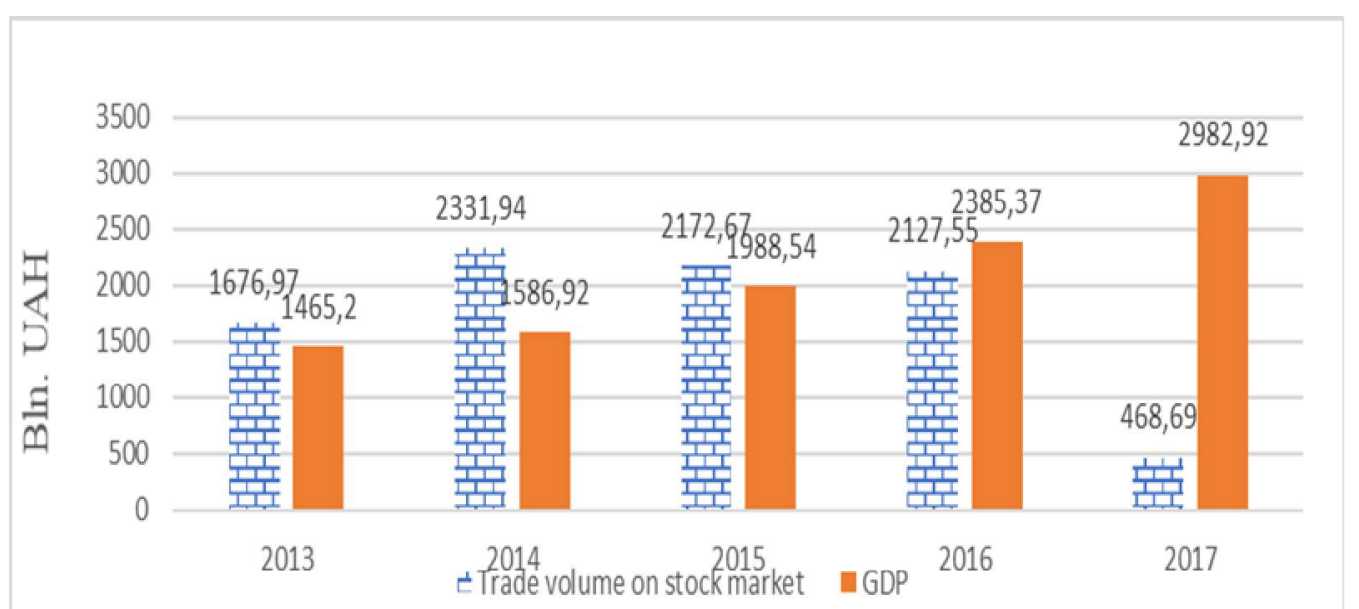

Fig. 3. Comparison of trade-volume on stock market and GDP in 2013-2017, Bln. UAH [5] 
In 2013 the trade-volume on stock market exceeded the GDP by more than a third. By the end of 2017 it makes only $15.71 \%$ of GDP. This indicates very low level of stock market development [5].

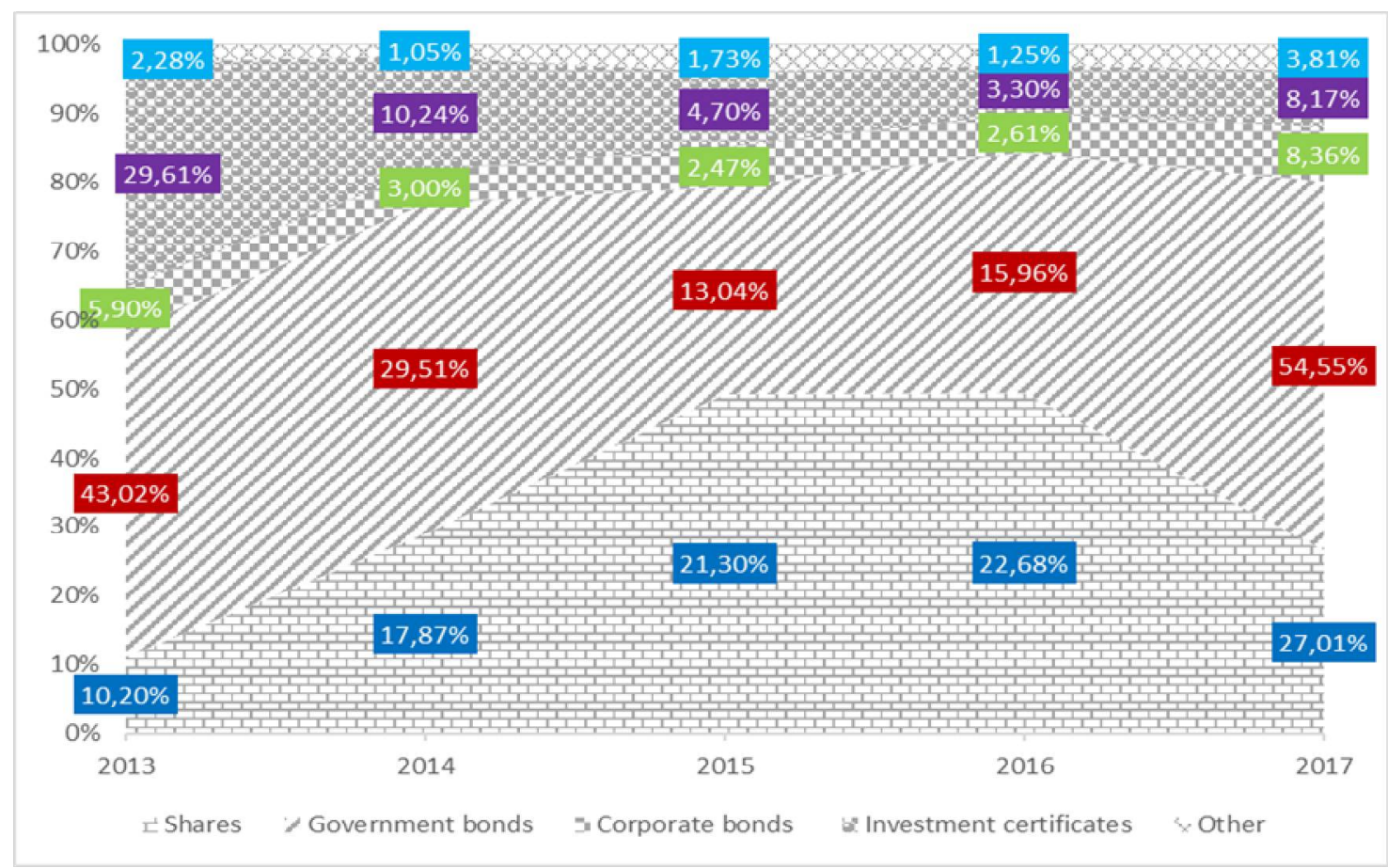

Fig. 4. Structure of trade-volumes by financial tools in 2013-2017, \% [5]

Government bonds make the biggest part in trading structure of the Ukrainian stock-market (54.55\%). Shares, the most popular trading tool on developed markets, makes only $27,01 \%$ (Fig. 4) The share of corporate bonds has increased to $8,36 \%$. Investment certificates make $8.17 \%$ of the market.

The share of other financial tools (derivatives, voxels, promissory notes, certificates of deposits, etc.) did not exceed $4 \%$ during all the period [5].

Such market structure indicates that Ukrainian stock market is dominated by government sector. Also, this structure characterizes Ukrainian stock market as poorly developed.

The level exchange market development is an important indicator of stock market development in whole. Ukraine has a structure with 3 main stock exchanges.

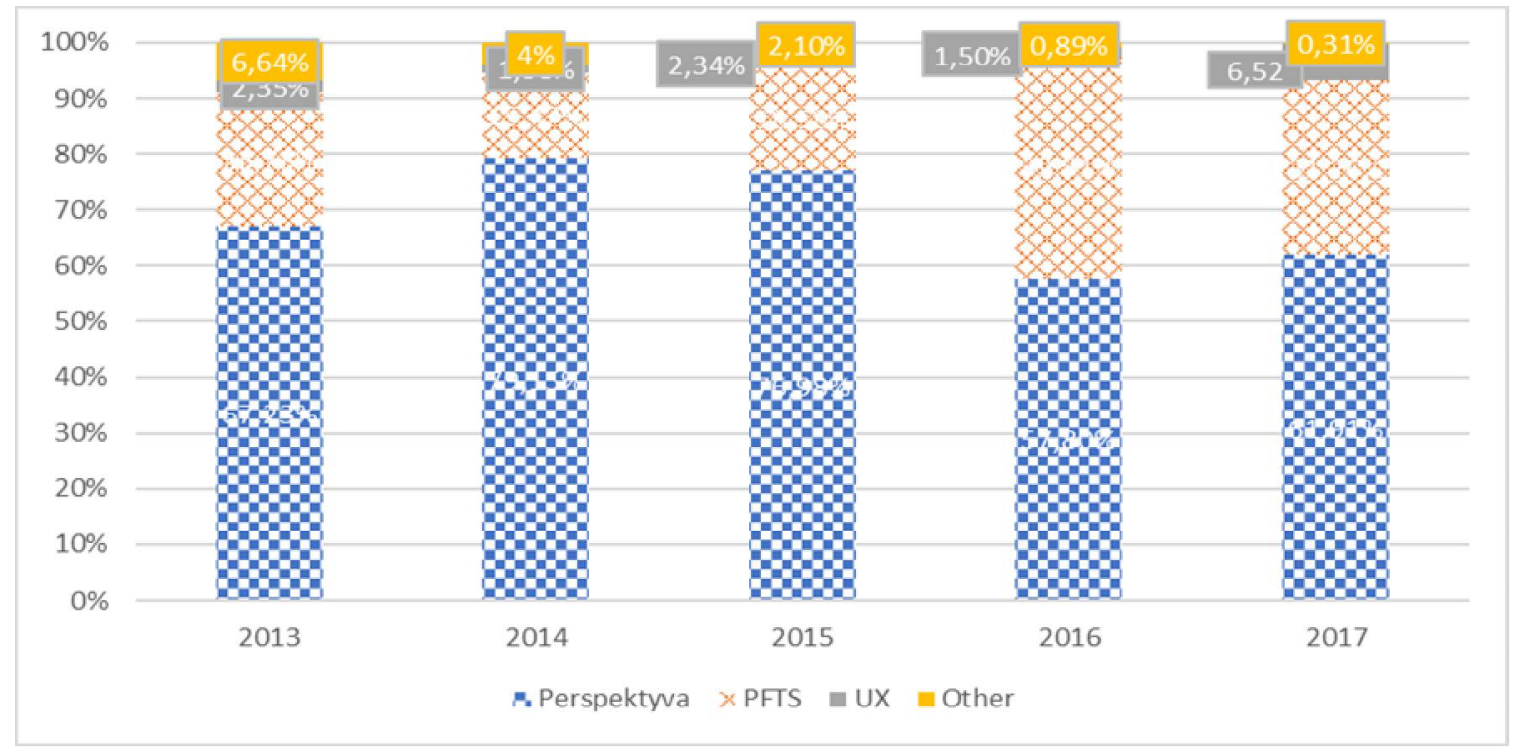

Fig. 5. Trade structure by stock exchange in 2013-2017, \% [1, 2, 3, 4, 5] 
«Perspektyva» makes more than $50 \%$ of the market during all the period. This is explained by specialization of this stock exchange. «Perspektyva» mostly trade government bonds, the most popular tool on Ukrainian stock market.

The share of «PFTS» was $31.26 \%$ by the end of 2017 . This exchange is a leader in equities and corporate bonds trade.

The share of «Ukrainian Exchange» (UX) has reached 6.52\% in 2017. UX is the second biggest exchange in equities trade and third biggest in government and corporate bonds trade.

The share of other exchanges does not exceed $1 \%$ by the end of 2017 [1, 2, 3, 4, 5].

Exchange market is also completely dominated by government bonds (92.10\%). Shares make only $2.45 \%$ of the market, which is very low number. The share of corporate bonds has dropped from $10.25 \%$ in 2013 to $2.97 \%$ in 2013. Other financial tools, including derivatives, do not make more than $3 \%$ of the market.

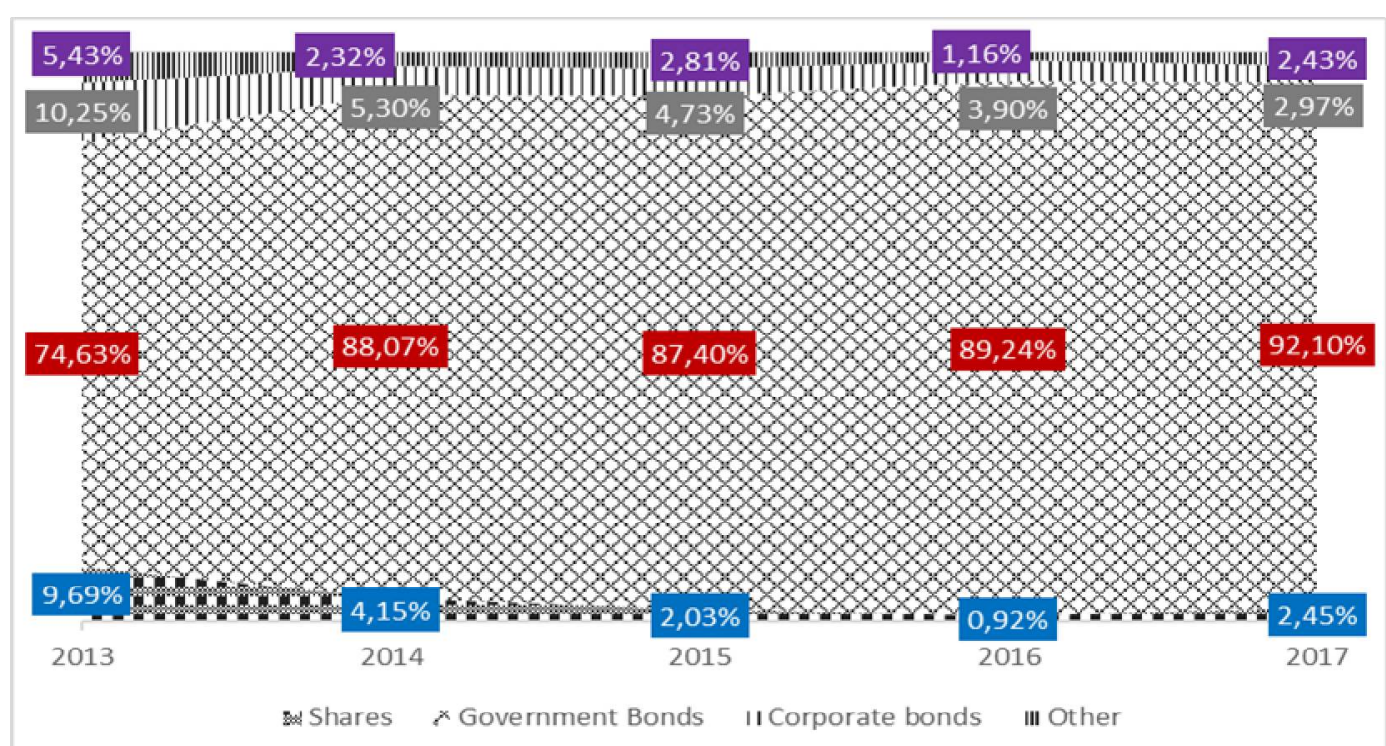

Fig. 6. Trade structure on exchange market by financial tools in 2013-2017, \% [5]

Nevertheless, Ukrainian stock market is also characterized by some positive dynamics (Fig. 7)

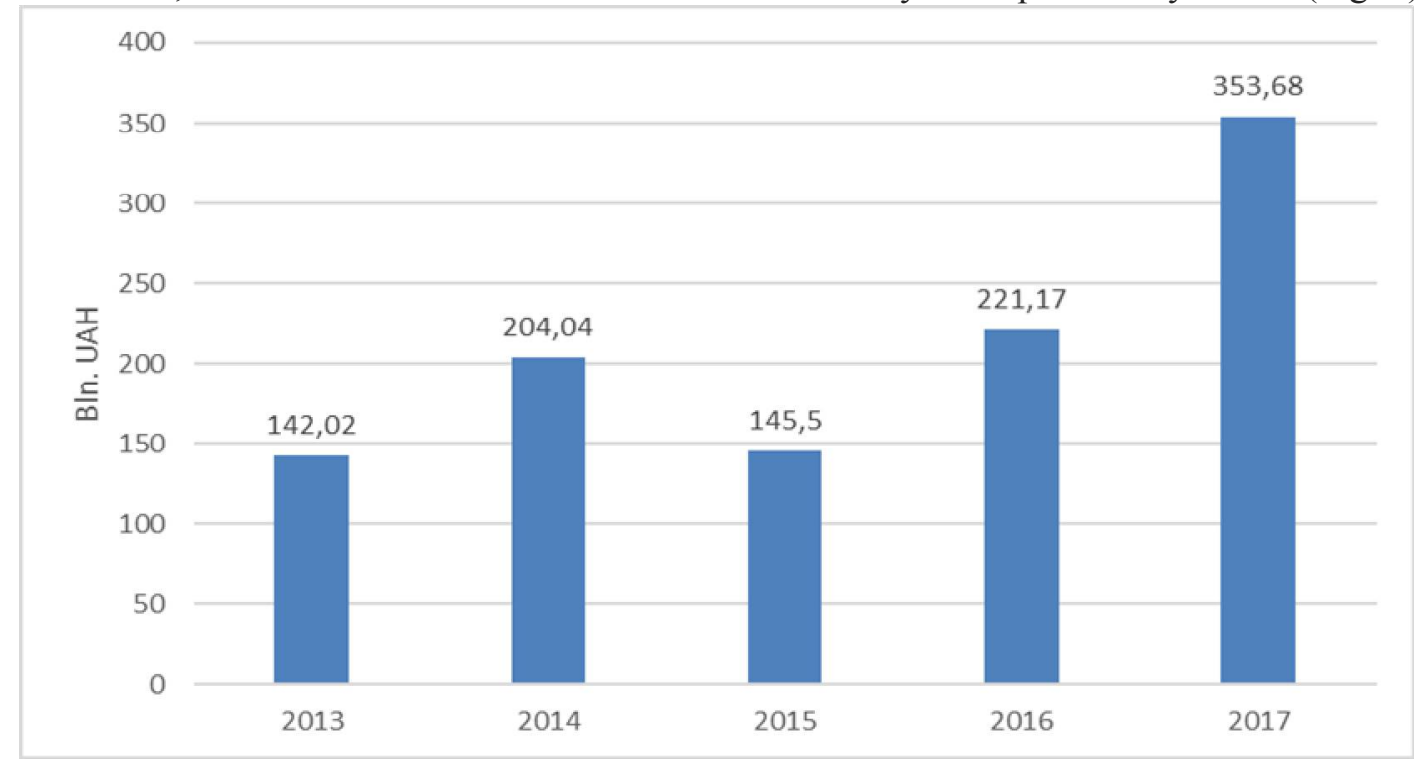

Fig. 7. Emission of new securities in 2013-2017 BIn. UAH [5]

The volume of emission of new securities has grown up from 221,17 Bln. UAH in 2016 to 353,68 Bln. UAH in 2017 (+37.46\%). Equites makes the biggest share among newly released securities $(91.98 \%)$.

This indicates that Ukrainian stock market slowly recovers from crisis. If this trend will continue, the structure of Ukrainian stock market will become healthier. 
Conclusions. Summing up, it can be argued that the Ukrainian stock market is still stagnant. Despite the positive dynamics of key indexes in 2017, the decline in trading volume indicates a low activity on the domestic securities market. The structure of the stock market is also unsatisfactory. The largest share in the structure of trades is occupied by government securities. The volume of shares remains low compared to the markets of developed countries. Derivative financial instruments are poorly developed and practically not used by Ukrainian investors. Although, Ukrainian stock market demonstrates some signs of recovery, further improvements are needed to claim Ukrainian stock market to be healthy and attractive for investors.

So the main problems of the functioning of the domestic stock market can be considered: insufficient resource supply of the national stock market (including large-scale shortage of domestic money resources for investments); the system of counteraction to the legalization (laundering) of the proceeds from crime is not well-established; low liquidity and capitalization of the stock market; insufficient legislative regulation of pricing in this market; limited amount of liquid and investment-attractive financial instruments; high fragmentation of the stock exchange and depositary structure.

In the course of the research, the main directions of the stock market development were identified, namely:

- the development of corporate reform, improving the efficiency of issuers' regulation, expanding instruments in the stock market;

- stimulation of inflow of investments into the stock market;

- ensuring the reliable and efficient functioning of the market infrastructure; climate.

- ensuring the functioning of a single state policy to stimulate the improvement of the investment

A priority area is also the development of a stock market regulation concept, which will include a mechanism that will help to solve the following: increasing capitalization, liquidity and transparency of the stock market; improvement of market infrastructure and ensuring its reliable and efficient functioning; improvement of mechanisms of state regulation and protection of investors' rights.

\section{REFERENCES:}

1. Zvit NKTsPFR za 2013 rik // Natsionalna komisiia z tsinnykh paperiv ta fondovoho rynku [Report for 2013 National Securities and Stock Market Commission] Retrieved from https://www.nssmc.gov.ua/documents/rtchniy-zvt-nktspfr-za-2013-rk/

2. Zvit NKTsPFR za 2014 rik // Natsionalna komisiia z tsinnykh paperiv ta fondovoho rynku [Report for 2014 National Securities and Stock Market Commission] Retrieved from: https://www.nssmc.gov.ua/documents/rtchniy-zvt-nktspfr-za-2014-rk/

3. Zvit NKTsPFR za 2015 rik // Natsionalna komisiia z tsinnykh paperiv ta fondovoho rynku [Report for 2015 National Securities and Stock Market Commission] Retrieved from https://www.nssmc.gov.ua/documents/33518/

4. Zvit NKTsPFR za 2016 rik // Natsionalna komisiia z tsinnykh paperiv ta fondovoho rynku [Report for 2016 National Securities and Stock Market Commission] Retrieved from https://www.nssmc.gov.ua/documents/rtchniy-zvt-nktspfr-za-2016-rk/

5. Zvit NKTsPFR za 2017 rik // Natsionalna komisiia z tsinnykh paperiv ta fondovoho rynku [Report for 2017 National Securities and Stock Market Commission] Retrieved from https://www.nssmc.gov.ua/documents/rtchniy-zvt-nktspfr-za-2017-rk/

6. Nazarenko L.V. Vyznachennia sutnosti poniattia «fondovyi rynok»/ [Definition of the essence of the concept of "stock market"] // Problemy i perspektyvy rozvytku bankivskoi systemy Ukrainy. - Vyp. 40., 2014, p. 211-217.

7. D. Bazylevych, V.D. Sheludko, V.V. Virchenko Fondovyi rynok (Stock market) pidruchnyk: u 2 kn. Kyiv:Vyd. Znannia, 2015. p.621.

8. Indeks PFTS (Ukraina)( PFTS Index - Ukraine) // Finansovyi portal «Minfin» Retrieved from http://index.minfin.com.ua/stock/?pfts

9. Ukraine $U X / /$ Investing.com - Retrieved from: https://ru.investing.com/indices/ukraine-uax-char

\section{УДК 336.76}

Завора Таїна, кандидат економічних наук, доцент. Полтавський національний технічний університет імені Юрія Кондратюка. Кузьменко Євгеній. Білостоцька політехніка, Білосток, Польща. Аналіз фондового ринку та перспективні напрями його розвитку. Виконано аналіз фондового ринку України, який включає такі компоненти, як аналіз обсягів торгів на фондовому 
ринку за різні періоди, капіталізації та фондових індексів, структури фондового ринку за організаторами торгів, а також структури фондового ринку в розрізі інструментів.

Визначено особливості й основні проблеми функціонування фондового ринку в умовах вітчизняної економіки, зокрема: скорочення обсягів торгів; низький рівень капіталізації фондових бірж України та біржової торгівлі; пасивність значної частини національних підприємств щодо здійснення операцій на фондовій біржі; невідповідність біржової торгівлі світовим тенденціям; недостатня прозорість українського фондового ринку.

Обгрунтовано, що фондовий ринок $\epsilon$ основним фінансовим ринком, здатним акумулювати фінансові ресурси, а також важливим інструментом проведення інноваційної політики. Визначено, що пріоритетним напрямом розвитку є розроблення концепції регулювання фондового ринку, яка буде включати механізм збільшення капіталізації, ліквідності та прозорості фондового ринку; удосконалення ринкової інфраструктури та забезпечення її надійного й ефективного функціонування; удосконалення механізмів державного регулювання та захисту прав інвесторів.

Ключові слова: фондовий ринок, фінансова нестабільність, акції, облігації, ліквідність, капіталізація, фінансові інструменти.

\section{UDC 336.76}

Zavora Taina, $\mathrm{PhD}$ (Economics), associate Professor. Poltava National Technical Yuri Kondratyuk University. Kuzmenko Yevhenii. Politechnika Białostocka, Białystok, Poland. Analysis of the stock market and perspective directions for its development. The analysis of the stock market of Ukraine was conducted. The peculiarities and main problems of functioning and perspective directions of development of the stock market in the conditions of the national economy are determined. It is substantiated that the stock market is the main financial market which able to accumulate financial resources, as well as an important tool for conducting innovation policy. It is determined that the perspective direction for development of the concept of regulation of the stock market will include a mechanism for increasing the capitalization. Liquidity and transparency of the stock market also will be the priority direction of development. As follows it will ensure improvement of market infrastructure and its reliable and efficient functioning; improvement of mechanisms of state regulation and protection of investors' rights.

Key words: stock market, financial instability, stocks, bonds, liquidity, capitalization, financial instruments.

\section{УдК 336.76}

Завора Таина, кандидат экономических наук, доцент. Полтавский национальный технический университет имени Юрия Кондратюка. Кузьменко Евгений. Белостокская Политехника, Белосток, Польша. Анализ фондового рынка и перспективные направления его развития. Проведен анализ фондового рынка Украины, включая такие компоненты, как анализ объемов торгов на фондовом рынке за различные периоды, капитализации и фондовых индексов, структуры фондового рынка по организаторам торгов, а также структуры фондового рынка в разрезе инструментов. Определены особенности и основные проблемы функционирования фондового рынка в условиях отечественной экономики, в часности это сокращение объемов торгов; низкий уровень капитализации фондовых бирж Украины и биржевой торговли; пассивность значительной части национальных предприятий по осуществлению операций на фондовой бирже; несоответствие биржевой торговли мировым тенденциям; недостаточная прозрачность украинского фондового рынка. Обосновано, что фондовый рынок является основным финансовым рынком, способным аккумулировать финансовые ресурсы, а также важным инструментом проведения инновационной политики. Определено, что приоритетным направлением развития является разработка концепции регулирования фондового рынка, которая будет включать механизм увеличения капитализации, ликвидности и прозрачности фондового рынка; совершенствование рыночной инфраструктуры и обеспечение еe надежного и эффективного функционирования; совершенствование механизмов государственного регулирования и защиты прав инвесторов.

Ключевые слова: фондовый рынок, финансовая нестабильность, акции, облигации, ликвидность, капитализация, финансовые 